\title{
A Suitability Of Competency Certification Scheme For Automotive Vocational High School With LSP P1 Against Business and Industrial World Needs In Semarang City
}

\author{
Dhewa Frovihandika ${ }^{1}, Z_{\text {Zainal Arifin }}{ }^{2}$,Eva Widiastuti ${ }^{3}$ \\ \{dhewahandika@gmail.com ${ }^{1}$, zainalarifin@gmail.com², evawidya04@gmail.com³ \\ Graduate School of Technological \& Vocational Education, Universitas Negeri Yogyakarta, Indonesia ${ }^{1}$ \\ Department of Technological \& Vocational Education, Universitas Negeri Yogyakarta, Indonesia ${ }^{2}$ \\ Graduate School of Technological \& Vocational Education, Universitas Negeri Yogyakarta, Indonesia ${ }^{3}$
}

\begin{abstract}
This research was aimed at identifying certification scheme that is done by automotive Vocational High School with LSP P1 in the field of Engine EFI and Conventional Tune Up and find out the mismatch between industrial needs that require labor skilled work in their fields. The result showed that (1) the competency scheme which was done is divided into 13 competency standards and 118 basic competencies; (2) all the competency standards which were done by automotive Vocational High School with LSP P1 was needed by industrial: (3) the basic competency in competency standard of service maintenance and engine repairing management system was still low; (4) the basic competencies that were still not done yet are injection pump checking, actuator/sensors repairing, emission limitation, distributor detachment, and battery poles attachment; (5) the suitability level of competency scheme against the work competency required by industrial has an average percentage of $91 \%$.
\end{abstract}

Keywords: Certification, LSP P1 automotive, Industrial Needs

\section{Introduction}

Indonesia is part of the Association of Southeast Asian Nations (ASEAN). ASEAN forms ASEAN Economic Community (AEC) program in accordance with ASEAN 2020's vision of creating a stable, prosperous, and highly competitive economic region, accelerating trade in production and services and increasing professionalism (Bustami, 2008: 5). AEC does not only open the flow of trade in goods or services but also the professional labor market (Pramudyo, 2014: 92). AEC presents a challenge for Indonesia, to prepare Indonesian manpower or human resources to compete in the AEC region. Graduates of Technology Vocational High Schools (SMK) who have high competencies are important conditions for entering global competition in the future. With the increasingly limited opportunity to enter the workforce for graduates of Technology Vocational Schools, the competition between workers in entering the work field in the industry is getting tighter (Seidel, 2008: 15).

Industrial revolution 4.0 marked the development of technology and information that is very extraordinary, the development of information technology that is so rapid must be adapted to adequate individual skills. A person's skills and capacity must be increased to meet 
changing times. labor competency becomes an important thing in the era of industrial revolution 4.0, especially nowadays there is still a mismatch between industrial needs that require skilled workforce according to their fields with minimum human resources. Education and skills are important for the state in creating quality and dignified human resources (HR). Vocational education is a necessity so that workers can continue to compete in entering the fourth industrial revolution. Efforts to prepare as much as possible to welcome this era need to require new skills so that the preparation of human resources with competencies is in accordance with the development of existing technology. Increasing one's capacity can be realized through a training course and certification. the importance of certification of expertise in certain fields can provide benefits for workers so that they can truly enter the labor market in accordance with industrial needs. Increased competency of Indonesian HR can be improved through vocational vocational programs, vocational vocational programs can improve HR competencies through education curriculum since primary education to prepare a competitive and productive millennial generation.

The quality of human resources is one of the factors that influence competitiveness in the AEC. Humans as sources of all powerful resources remain the main key to winning free market competition (Sudira 2012: 60). The competency test device is a measurement instrument used to test the specific competencies of prospective graduates of SMK Teknologi in accordance with the needs of specific competencies in the industry (Suhartadi, 2011: 157).According to the 2017 Global Human Capital Report, the quality of Indonesian human resources is ranked 65 th out of 130 countries. On average, the quality of Indonesian human resources is still lower compared to the other ASEAN countries. Based on the absorption values of human resources and the unemployment rate, Indonesia ranks 82 of 130 countries (World Economic Forum, 2017). This number shows that there are still many workers who have not been absorbed.

Another thing that is also related to the free flow of expert labor which refers to the approval of the MRA (Mutual Recognition Agreement). MRA is an opportunity recognized by ASEAN member countries to mutually recognize assessment aspects such as test results or in the form of a competency certificate (Pramudyo, 2014: 93). This has an impact on Indonesian workers because Indonesian labor productivity is still low, skills and expertise are still inadequate, making it increasingly difficult to compete in entering the AEC.

Vocational education is secondary education that prepares students to work in certain fields (Sudira, 2012: 13). Vocational education covers various fields of expertise that are tailored to the business world and the industrial world. Vocational education is very important for students to face global challenges in accordance with the capabilities that are owned and needed in the developing world of work.

Based on the Decree of the Director of Vocational Training, Vocational High School that already have LSP P1 must carry out the Competency Certification Test for XII grade students in accordance with the scheme contained in the LSP. The central government also stipulates that Vocational High School which have P1 license are required to take competency certification. The certification is useful for fortifying themselves from free market competition and after the implementation of the AEC. Based on BNSP data collection, there are 48 LSP P1 established by Vocational High Schools in Central Java Province. In the city of Semarang there are 4 technology and engineering Vocational High Schools that have LSP P1 in the field of light vehicle engineering.

Based on the data there are 4 Vocational High Schools that have had LSP P1 consisting of 4 Public Vocational School. Each Vocational High School uses a certification scheme that is almost the same, namely Conventional Tune Up Engine and Tune Up Efi Engine. Based on 
preliminary observations obtained a number of data of Vocational High Schools graduates majoring in Light Vehicle Engineering in 2016/2017 can be seen in the following table,

Table 1. The Data of Vocational High Schools graduates majoring in Light Vehicle Engineering in 2016/2017

\begin{tabular}{cccc}
\hline School & Working in DUDI & Still not gotten job & Still in college \\
\hline SMK 1 & 85 & 41 & 15 \\
SMK 3 & 40 & 25 & 5 \\
SMK 4 & 37 & 25 & 7 \\
SMK 7 & 50 & 12 & 10 \\
Total & $212 / 60 \%$ & $103(29 \%)$ & $37(11 \%)$ \\
\hline
\end{tabular}

Based on vocational graduation data in Semarang city in the 2016/2017 school year. All of the above Vocational High School graduates have taken competency exams conducted by LSP P1 with competency schemes for the Conventional Tune Up Engine and EFI Tune Up Engine and are declared competent. Furthermore, the data above shows that $60 \%$ of SMK students are absorbed in DUDI, $11 \%$ of graduate students go to college while $29 \%$ have not gotten a job. This shows that all competency-certified Vocational High Schools graduates have not been fully absorbed in DUDI. This is reinforced by the data of the open unemployment rate according to education in Semarang city in 2015 as follows:

Table 2. The data of the open unemployment rate of Semarang city in 2015

\begin{tabular}{lccc}
\hline Education & Open Unemployment & Workforce & Rate (\%) \\
\hline Elementary School & 7.906 & 121.011 & 6.53 \\
Junior High School & 10.063 & 140.434 & 7.16 \\
Senior High School & 12.879 & 200.864 & 6.41 \\
Vocational High School & 28.233 & 193.639 & 14.5 \\
Diploma & 1.332 & 33.693 & 3.95 \\
Undergraduate & 4.797 & 106.791 & 4.49 \\
\hline
\end{tabular}

The unemployment rate in Semarang is quite high. This indicates that the level of labor absorption in Semarang is quite low. Based on data obtained from the National Labor Force Survey BPS in Central Java, the highest unemployment rate of Vocation High School graduates was 28,233 of the total available workforce of 193,639 or around $14.5 \%$.

It contrasts with the certificate obtained by students, the competency certificate obtained by students should be used to get added value because the competency certificate owned by the student means that they have special skills according to the scheme determined by the school in accordance with DUDI requirements.

Education, training and special skills related to vocational for career development. The process of developing one's career and skills requires education and training called vocational education. Vocational education learns the nature of work, aspects of work, career path through developing competencies needed by the Industrial World (Sudira, 2016:5).

Vocational Education is a secondary education that prepares students especially to work in certain fields. One of the efforts to improve the quality of human resources is through formal education and training, namely vocational schools (Ngadi, 2014: 60). According to UNESCO 2006 Technical and Vocational Education and Training (TVET) is concerned with the acquisition of knowledge and skills for the world of work. Vocational education prepares knowledge and skills for students to enter the workforce in accordance with the needs of the 
workforce. The purpose of vocational education is to prepare someone for entering the workforce, this is in accordance with Pavlova (2009: 7) who was stating "direct preparation for work is the main aim of vocational education". Vocational education does prepare graduates who are ready to work. According to Judisuseno (2008), only vocational schools are able to follow the needs of DUDI which are seen as preparing quality workforce. Development of a vocational education curriculum based on competencies that are needed in DUDI. Bartetzko A. (2004: 201) competencies expected in students, especially in entering the workforce, namely: a) ability to cooperate and communicate; b) problem solving and technical capabilities; c) self-management; d) learning; e) initiative and enterprise; f) personal attributes such as loyalty, integrity. This explains the importance of vocational education in which the graduates are expected to be absorbed in DUDI. Learning in Vocational Schools must be carried out in such a way that graduates are truly ready to enter the workforce, in the sense of having the knowledge, skills and attitudes needed in the world of work (Rindiantika, (2017: 39). Demands between the world of education and the world of work in the broadest sense indicate the need to master a number of competencies that can be demonstrated at work (Suryanto, 2013: 229).

Competency is something that must be mastered by students in Vocational High School, states that competence is a skill developed in a pattern (Bradley, (2003: 170). This is in accordance with the objectives of vocational high education, namely to equip students with knowledge, technology and competencies that are in accordance with their expertise program. The competencies that are put forward by SKKNI are more oriented towards supporting skills in certain positions, a description of abilities that includes the knowledge, skills and work attitudes that must be possessed by a person. This is in accordance with Spencer \& Spencer (1993), workers from school graduates who have the competence in accordance with the needs of the company will be needed by the company. Sashkin (1993: 163-186) stated "If a graduate enters the world of work, the expected competencies are competencies that are able to improve company performance, in this case the company's performance in the era of globalization refers to productivity to win the competition". Career control and networking are competencies that have a strong relationship to career success, thus providing an illustration that in addition to engineering competencies, namely adaptability, the ability of career control and network interactions can provide an important role in the performance of success in work (Kuijpers,2006: 169).

According to the 2014 BNSP guidelines no 201 on the general requirements of the Professional Certification Institute states that the Professional Certification Agency (LSP) is an implementing agency for professional certification activities that obtain a license from BNSP after fulfilling the requirements that have been established to carry out work competency certification. In carrying out the duties and functions of the LSP, it refers to the BNSP guidelines. The guidelines stipulate requirements that must be adhered to ensure that the certification body runs a certification system in a consistent and professional manner, so that it can be accepted at the national level for the benefit of human resource development in terms of improving quality and work protection. Workers who will get recognition for their field of competence, can submit a competency test process through LSP that is appropriate to their profession (Standsyah, 2017: 6). According to the 2014 BNSP Guidelines on general requirements, LSP states that professional certification schemes are specific certification requirements relating to professional categories that are determined using the same specific standards and rules and the same procedures. According to BNSP Guidelines No. 210 of 2014 concerning the development and maintenance of certification schemes, the certification schemes consist of several types, as follows: 1) Scheme of certification of the Indonesian 
national qualification profession, 2) national occupational qualification certification scheme, 3) cluster professional certification scheme / package, 4) professional competency unit certification scheme, 5) proficiency certification.

\section{Method}

This type of research used quantitative descriptive research with survey research methods. Survey research is a research carried out on large/small populations, the data studied is taken from the population so that it can be found in reactive events, distribution and relationships between variables (Wirartha, 2006). Survey research took samples from a population and used questionnaires as a data collection tool. The aim of this research was to describe the actual situation regarding the suitability between the competency certification schemes implemented in Vocational Schools with DUDI needs in Semarang. This research was carried out in 4 Vocational Schools that have had LSP P1 in Semarang city and some DUDI which collaborated with the schools, both official Brand Holder Agent (APM) workshops and general workshops in accordance with applicable criteria. The time of the study was held in April-July 2018.

The population in this study were all productive teachers in 4 Light Vehicle Engineering Vocational High Schools which had LSP P1 in the city of Semarang totaling 28 people, namely SMK Negeri 1 Semarang, SMK Negeri 3 Semarang, SMK Negeri 4 Semarang and SMK Negeri 7 Semarang. Public and official workshops that would be used as a population were 20 workshops consisting of 10 official workshops / APM and 10 general workshops spread across Semarang city. Each workshop takes 1 (one) sample as the head of the service manager and the mechanical head (Foreman) in the field of Light Vehicle Engineering.

The research instrument was a tool used to collect the data. This study used an instrument based on Competency Standard and Basic Competency from learning materials carried out by schools through LS1 P1 in Semarang City. Expert judgment was used in this research in validating the instrument. The aim of using the expert judgment was so that the instrument has the right content validity through various inputs, suggestions and improvements from experts. Experts were asked to observe carefully all items in the test that will be validated, then they were asked to correct items that have been made. To find out the validity of the instrument, the researcher asked for consideration, instructions and suggestions from experts from the chairman of the Yogyakarta LSP and the lecturers of the Faculty of Engineering, Yogyakarta State University.

Data analysis techniques in this study used descriptive analysis techniques which presented data for each instrument using descriptive analysis with the percentages. According to Riduwan, (2013: 22) an item is said to be good if it meets the following criteria:

Table 3. Percentage of suitability

\begin{tabular}{cc}
\hline Percentage & Criteria \\
\hline $81 \%-100 \%$ & Really suitable \\
$61 \%-80 \%$ & Suitable \\
$41 \%-60 \%$ & Less suitable \\
$21 \%-40 \%$ & Not suitable \\
$0 \%-20 \%$ & Really not suitable \\
\hline
\end{tabular}


A competency item is stated to be suitable if the percentage is more than $61 \%$. In this case the percentage is obtained based on the average value of the percentage of competencies needed by $D U D I$.

\section{Results And Discussion}

This research was carried out in several stages. The first stage was observing State Vocational High School 1 Semarang as a vocational school that had a license of automotive LSP P1. The second stage was to verify the competency standard and basic competency based on the curriculum obtained and then given to automotive teachers in Semarang city Vocational High Schools whose Vocational Schools have P1 LSP, namely State Vocational High School 1, State Vocational High School 3 Semarang, State Vocational High School 4 Semarang and State Vocational High School 7 Semarang. The third stage verified the competencies in the scheme in the form of questionnaires to DUDI, APM, and general workshops in Semarang city.

Based on the results of research conducted at LSP P1 in State Vocational High School 1 Semarang, a curriculum based on SKKNI was obtained and it divided into 13 competency standards (SK) and 118 basic competencies (KD). All vocational schools with LSP P1 license in Semarang city carry out all competency standards provided by LSP P1, this can be known based on a percentage of $100 \%$.

Competency standards for automotive programs in the Tune Up Efi Engine and Conventional Engine Tune Up that are carried out by Vocational High School are all needed by $D U D I$ in Semarang city. Each competency standard has a high percentage. So that it can be said that all automotive competency standards implemented by LSP P1 Vocational High Schools are needed by DUDI. This can be known based on the average automotive competency standards in the Efe Tune Up Engine and Conventional Tune Up Engine which has a percentage of $91 \%$.

Table 4. Automotive LSP P1 Competency Standards in the field of Engine Tune Up Efi and conventional Engine Tune Up required.

\begin{tabular}{lc}
\hline \multicolumn{1}{c}{ COMPETENCY STANDARDS } & $\%$ \\
\hline Follow Health Procedures and Work safety & 94 \\
Maintain Equipment and Workplace Equipment & 94 \\
Using and Maintaining a Measuring Instrument & 90 \\
Reading and Understanding Technical Drawings & 88 \\
Maintain / Service Engine and its Component Components & 94 \\
Repairing the Ignition System & 89 \\
Test, Maintain / Service and Replace the Battery & 92 \\
Maintain / Service of Gasoline Fuel Systems & 90 \\
Maintain / service the cooling system and its components & 92 \\
Implement Component Maintenance / Service & 91 \\
Communication Contribution at Work & 97 \\
Maintain / Service and Improve System Management Engine & 80 \\
Maintaining / Servicing an Emission Control System & 88 \\
\hline
\end{tabular}


Some basic competencies that have a low value in maintain service and improve the engine management system competency standard, namely checking the signal NE, checking the CKP signal, operating the oscilloscope and reading the oscilloscope signal.

Table 5. Basic competencies that have a low value

\begin{tabular}{lc}
\hline \multicolumn{1}{c}{ COMPETENCY STANDARDS } & $\%$ \\
\hline Checking the signal NE & 60 \\
Checking the CKP signal & 58 \\
Operating the oscilloscope & 38 \\
Reading the oscilloscope & 35 \\
\hline
\end{tabular}

Some basic competencies are needed in order to keep follow of increasingly advanced technology, some additional basic competencies such as checking injection pumps, repairing actuators / sensors, identifying government provisions regarding permitted gas emission limits and providing appropriate solutions in reducing exhaust emissions, releasing distributors, connecting battery poles / terminals is the basic competency required by DUDI but it was not implemented in vocational schools with LSP P1 license. The competency standard is one of the benchmark components in carrying out maintenance of the conventional engine tune up and tune up efi. Competency standards in the automotive field carried out at Vocational High Schools with LSP P1 with conventional engine tune up and efi tune up schemes have an average percentage of $91 \%$ so that it can be said that the competency standards implemented by P1 SLS have a high level of suitability to the DUDI needs in Semarang city. The suitability of the competency standards carried out in $D U D I$ Vocational Schools has an important role to prepare personnel who have the skills and knowledge that are in line with DUDI's needs and are able to develop their potential in adopting and adapting to technological developments to meet the 4.0 industrial revolution era. The level of conformity between competency standards has different results, this shows how much competency standard and basic competency are needed to be carried out in DUDI. The greater the level of suitability, the more competency is used in DUDI because these competencies are part of the maintenance of the conventional engine tune up and tune up efi. The competencies needed in DUDI will increase along with the development of increasingly advanced technology. All competencies in the maintenance of conventional engine tune ups and efi tune ups are still needed in the present and in the future. An increasingly advanced technology will produce a new competence. This shows that the competency level of each workshop is different.

\section{Conclusion}

The LSP P1 Competency Scheme for Conventional Tune Up Efi Engine Automation and Engine Tune Up programs implemented by automotive Vocational High Schools with LSP P1 is divided into 13 competency standards and 118 basic competencies. All competency standards and basic competencies are carried out by licensed Vocational High School with P1 and DUDI in Semarang city. Some basic competencies in standard competency improve the management systems, namely (1) checking signal NEs; (2) checking CKP signals; (3) operating the oscilloscope and (4) reading the oscilloscope signal is not required DUDI. Some basic competencies are needed by DUDI: 1) checking the injection pump; (2) repairing actuators/sensors; (3) limits on permitted exhaust emissions (4) discharge of distributors, (5) 
jumping batteries. Competency standards in the automotive field carried out at Vocational High School with LSP P1 with conventional engine tune up scheme and efi tune up have a percentage of $91 \%$ so that it can be said to have a high level of suitability. this shows that these competencies can be used in facing the demands of the times in the era of industrial revolution 4.0. The process of competency standard and basic competency preparation in implementing the basic program of the Tune Up Efi Engine Automation and Conventional Tune Up Engine implemented by automotive Vocational High School with P1 LSP must be preceded by an analysis of the competency needs which is required by DUDI and the existence of a collaboration between Vocational High Schools and DUDI in determining competency standard and basic competency so that competency competencies needed by industry can be mastered by students and the public ready in the face of 4.0 industrial revolution. 


\section{References}

[1] Bartetzko A.: Key competencies, employability skills and the new training organisation; Knowledge Tree e-journal; http://www.ncver.edu.au/generic. htm.10 - 112017 (2004)

[2] Bradley, D. H. S.: Validating Competency at the Bedside.Journal For Nurses In Staff Development, 19 (4),165-173 (2003)

[3] Bustami, Gusmardi.: Menuju Asean Economic Community 2015. Direktorat Jendral Kerjasama Perdagangan Internasional departemen Perdagangan Indonesia, Jakarta (2008)

[4] Judisuseno, R. K.: Jadilah Pribadi Yang Kompeten di Tempat Kerja. PT Gramedia Pustaka Utama, Jakarta (2008).

[5] Kuijpers, M.A.C.T.,Schyns, B., \&Scheerens, J.: Career Competencies for Career Success. Journal The Career Development Quarterly volume 55, Desember 2006, 168-178 (2006)

[6] Ngadi.: Relevansi Pendidikan Kejuruan Terhadap Pasar Kerja Di Kota Salatiga. Jurnal Kependudukan Indonesia. Vol. 9 No. 1. (ISSN 1907-2902). Hal 59-70 (2014)

[7] Pavlova. M.: Technology and Vocational Education for Sustainable Development Empowering Individuals for The Future.: Springer Science Business Media B. V, Queensland (2009)

[8] Pramudyo, Anung.: Mempersiapkan Sumber Daya Manusia Indonesia Dalam Menghadapi Masyarakat Ekonomi Asean Tahun 2015. JBMA, Vol II, 92-100 (2014)

[9] Riduwan.: Skala Pengukuran Variabel-Variabel Penelitian. Alfabeta, Bandung (2013)

[10] Rindiantika, Yuni.: Pengembangan SMK Melalui Dunia Usaha Dan Industri (Dudi).Kajian Teoretik. Jurnal Intelegensia. Vol 1, No 2. Hal 37-45 (2017)

[11] Seidel, R.: Vocational Education and Training: Now What. Global Journal of Engineering Education, Vol 2. No 3 (2008)

[12] Sashkin, marshal dan kisser.: Putting total Quality management to Work. BerretKohler Publisher, San Francisco (1993)

[13] Sudira, Putu.: Filosofi dan Teori Pendidikan Vokasi dan Kejuruan. UNY Press, Yogyakarta (2012)

[14] Sudira, Putu.: TVET ABAD XXI Filosofi, Teori, Konsep, dan Strategi Pembelajaran Vokasional. UNY Press, Yogyakarta (2016)

[15] Suhartadi, Syarif.: Pengembangan Model Perangkat Uji Kompetensi Di Sekolah Menengah Kejuruan Teknologi Dalam Bidang Permesinan. Jurnal Teknologi Dan Kejuruan. VOL 34. No 2. September 2011: 155-164 (2011)

[16] Suryanto, Didik.: Relevansi Soft Skill yang Dibutuhkan Dunia Usaha/Industri dengan yang Dibelajarkan di Sekolah Menengah. Jurnal Pendidikan Sains. Vol 1. No 3. September 2013, Hal 228-236 (2013)

[17] Spencer, L.M \& Spencer, S.M.: Competence at Work: Models for Superior Performance. John Wileyn \& Sons, Inc, Washington DC (1993)

[18] Standsyah, R E.: Merode Logika Fuzzy untuk Analisis Kinerja Asesor Terhadap Hasil Asesmen Pelaksanaan Program Sertifikasi Kompetensi Kerja BNSP. Universitas DR Soetomo, Surabaya (2017)

[19] Wirartha, I, M.: Metode Penelitian Sosial Ekonomi. Andi, Yogyakarta (2006)

[20] World Economic Forum. The Global Human Capital Report 2017. (2017) 